DOI https://doi.org/10.36059/978-966-397-111-7/67-90

\title{
TRAGIC AND COMIC IN THE EVERYDAY LIFE OF THE URBAN POPULATION OF UKRAINE IN 1917-1920
}

\section{Popov V. Z.}

\section{INTRODUCTION}

The daily life of the population of industrial areas in the crisis of 1917-1920 could be characterized by a number of specific features. The existence of residents of large cities and workers' settlements was almost completely depended on the rural areas that were providing food supply. When economic ties were disrupted, the urban population found itself in a vulnerable position, unlike the villages, which had a significant degree of autonomy. The social structure of the urban population was quite diverse, which created the possibility of a comparative consideration of behavioral practices of various segments of the population. Some characteristics of urban life during the period of socio-economic changes were belonging to all groups, regardless of their social status. At the same time, there were specific behaviors inherent to the certain categories of citizens.

Frequent change of power, and, as a result, changing of the political course in 1917-1920; economic chaos, the blockade of many cities set the task of physical survival for the urban population, in order to solve it various technologies were undertaken. The person who lived in the city permanently satisfied a wide range of needs. In accordance with the nature of his needs, a functional typology of the urban environment was built, which was including industrial, residential and recreational facilities, systems of public centers, communication nodes. The main functions of open urban spaces were communication, commerce, recreation, information. Closed spaces required, first of all, comfort and safety. Events in 1917-1920 in Ukraine, fundamentally changed the basic characteristics of the urban environment of a person, the content of its functions, which respectively predetermined the daily activities of citizens.

Ordinary citizens, forced to fight for existence, repeatedly found themselves in situations that had two sides - the tragic and the comic. 
Laughter regarding the realities of the current time was one of the methods of survival in extreme conditions. It was a response to a psychological threat, a behavioral stress relief technique. The ironic interpretation of events gave a certain meaning to the meaninglessness of what was happening, saved from a sense of helplessness and despair in an aggressive environment. Perhaps the events of the past, perceived by us today with a smile, were causing quite different feelings and emotions among contemporaries. However, it is undoubtedly that politicians, journalists, and ordinary people could joke on any occasion. And with the deterioration of all aspects of everyday life, the reasons for irony did not become less. A feature of the social crisis was the disappearance of most of the ethical restrictions. The person began to laugh at what was previously considered as a mockery. He laughed when before an adequate man cried.

\section{Transformation in everyday behavior of the urban population of Ukraine}

The first months of the revolution in 1917 were marked by the growth of political activity of the most different sections of the urban population. The open places of Ukrainian cities were filled with crowds of protesters. In Odessa, people who felt an interest in politics, was gathering on the streets and squares. In the morning the big cafes were already crowded. The content of articles and telegrams was passed from mouth to mouth. Crowds gathered around the bookstores, where telegrams were hung on the windows. However, the first weeks already showed the opposite side of freedom - anarchy. According to the memories of Chernigov prison warden, Krainsky, the soldiers from the hospitals "lay side by side on the boulevards, and together with the female maidservants they got to such shamelessness that people around had to turn their sight away"1.

Becoming more extremist, various street actions posed a threat to the safety of citizens. In Balaclava in the summer of 1917, in the square filled with armed soldiers, there were shouts to the officers: "Put them damned to the bay", "what to look for, kill everyone", "they drank enough of our blood". The crowd moved to the hotel where the officers were living, but

\footnotetext{
${ }^{1}$ Центральний державний архів громадських об’єднань України (ЦДАГО), ф. 5, оп. 1, спр. 21, арк. Ззв., 7, 21.
} 
one soldier stopped the crowd with his performance ${ }^{2}$. During the demobilization of the army, after a cessation of arms with the Germans, city streets were filled with crowds of people in the gray overcoats. Almost every soldier had in his pockets gold and silver cigarette cases, watches and chains ${ }^{3}$.

Intelligent people considered it dangerous to walk the streets in the evening, and people locked themselves up, getting afraid to leave the house. Another phenomenon was a strange discrepancy. The public plunged into the endless fun. Daily posters reported upcoming dance parties. The most frequent places for arranging these parties were schools. Their directors were terrorized, and in order to please the students, they appeased them with the arrangement of parties. During the dances, young men kept themselves very cheeky with their ladies ${ }^{4}$.

With each new round of civil confrontation, the city residents felt themselves less and less secure, even on their own spaces - in houses and apartments. Food riots took place in the cities of Ukraine in the spring and summer of $1917^{5}$. When there was a shortage of bread in Chernigov, the crowd rushed through the apartments to search the intelligentsia. "Sugar, flour, cereals were taken from everyone, and also wallets, vodka and household things"

City residents were pretty scared by the bacchanalia of revolutionary elements. They perceived very painful the three-days battles in Kiev in November 1917. Even when the armed struggle was over, and life began to get better - newspapers came out again, trams returned ringing on the streets, theaters, educational institutions, cafes had been opened - anyway, Kiev citizens still didn't recover from their fright, and mostly talked "in a careful whisper, indefinite way"7. Gradually, the town population lost interest in meetings, and in general in politics. Instead of political actions, people preferred to spend time searching for and getting foodstuffs. Lines

2 Кришевский Н. В Крыму (1916-1918г.) // Архив русской революции. Том 13. Берлин, издательство «Слово», 1924 г. - С. 86.

${ }^{3}$ ЦДАГО, ф. 5, оп. 1, спр. 21, арк. 49, 50.

4 Там само, арк. 43.

5 Левкович М. Женщина в революции и гражданской войне на Украине. Харьков: Книгоспилка, 1928. - C. 49.

${ }^{6}$ ЦДАГО, ф. 5, оп. 1, спр. 21, арк. 28.

${ }^{7}$ Киевская мысль. № 139. 8 ноября 1917 г. 
for food and deficient industrial goods, so-called the "tails", have become a constant sign of the urban view.

The shortage of food forced thousands of citizens to go to other districts for foodstuffs to change their regular way of life. The Kharkov railway station was a gloomy spectacle. "The crowding, the suffocating half-light, the rustling of the gray human mass. Sacks, baskets, dirty bags on the shoulders and backs of gray human shadows are spinning. Faces are sweaty, stupidly passive, without fire and thoughts in their eyes. Lips habitually whisper curses, without passion and excitement. People lie and sit on the spat floor for three days" $"$.

In January 1918, Kiev residents first experienced artillery shooting at the city. Taken aback, the townspeople soon became comfortable with their new position. Almost immediately, they felt a lack of food, lack of light, and soon lack of water. The lack of water was felt especially strongly for several next days. "But the person adapts to everything, and soon everyone learned to use moments of calm in order to buy provisions in the next street, fill up a bucket of water in the monastery courtyard, as in the Middle Ages, get a few candles as precious as gold, and visit friends in remote districts that were less exposed to the bombardment than downtown".

In the conditions of revolutionary chaos, Kiev fell into collapse. "Starting from the largest, but untidy and dirty main railway palace, further along the main thoroughfares that led the visitor directly to the center of the city, traces of disorder were visible at every turn; it was obvious that the "hooligan" used a situation that was favorable to him - the struggle for power." Feeling free and unpunished, "hooligan" left an imprint of "dirt, groveling and shamelessness" on the entire metropolitan city ${ }^{10}$.

When the Odessa Military Revolutionary Committee announced the transfer of power into the hands of the Soviets, on January 15, 1918, a firefight began between the Bolsheviks and the Haidamaks. The shooting stopped on January 17. Cars with white flags were driving in the city. People appeared at their gates again. At first they were habitually stuck to

\footnotetext{
${ }^{8}$ Южный край. 9 мая 1918 г. № 20. C. 17.

9 Лейхтенбергский Г.Н. Воспоминания об «Украине». 1917-1918. Берлин: к-во «Детинец», 1921. -

${ }^{10}$ Омелянович-Павленко М.В. Спогади командарма (1917-1920): Документально-художнє видання / Упоряд.: М. Ковальчук. - К.: Темпора, 2007. - С. 73, 74.
} 
the walls, then grew bolder. The streets began to revive, providing its territory for daily human activities. In addition, the sensitivity of people to something that seemed unbelievable a few months ago was noticeably dulled. Although at one of the crossroads there were still pools of blood that no one cleaned, and pedestrians left red footprints on the sidewalks, between the pools "the Greek, a tradesman of oriental sweets, spread out his traveling table". There was no shortage in buyers ${ }^{11}$.

With the rise to power of Hetman P.P. Skoropadsky "tails" at bread shops began to disappear, and were replaced by lines at cinemas. The public were visiting the numerous cafes, the "longtime non-swept" streets were cleared, "brave policemen" appeared on them, but the trams already were moving at longer intervals than before, or even intermittently, for example, in Odessa" ${ }^{12}$. A student from Kiev recalled that "Kiev streets were always very busy, and during hetman's regimen, the Khreshchatyk street was impossible to go through. And the public was much more elegant than before" $"$.

Finnish Ambassador to Ukraine G. Gummerus remarked: "The old beautiful city has noticeably lost its rich appearance. The buildings were left unattended. Paving stones in many places were damaged. Even in the best hotels was present an impossible dirt"14. The hetman himself faced the consequences of Bolshevik's regimen in the city. Visiting an old friend in Kiev, Skoropadsky was upset by the "inhospitable impression" that her house made to him, because it was so cozy before the revolution. "It's nothing around, the windows are broken, the garden is ruined. It turns out that the Bolsheviks did a search here and brought the house into such a state" ${ }^{\prime 15}$.

In the cities, especially in Kiev, everything was filled with German culture: "German theater, German bookstore, touring German actors and musicians." German dialect sounded on the streets, "a lot of German women came from a starving homeland to eat bread and sugar in the

\footnotetext{
11 Російський державний архів соціально-політичної історії (РДАСПІ), ф. 71, оп. 34, спр. 102a, арк. 48.

${ }_{12}$ Кришевский Н. Указ. соч. - С. 124.

13 Дневник и воспоминания киевской студентки (1919 - 1920 гг.) // АРР, том 15. - С. 211.

${ }^{14}$ Гуммерус Г. Україна в переломні часи. Шість місяців на чолі посольства у Києві.: Пер. 3 фін. К.: ВПЦ «Київ. ун-т», 2004. - С. 56.

${ }^{15}$ Скоропадський П. Спогади. Кінець 1917-грудень 1918 рр. Київ-Філадельфія, 1995. - С. 119.
} 
newly conquered lands" "16. Everyone rushed to buy German books and learn German. The Germans were very kind, and made a charming impression of their culture and discipline ${ }^{17}$.

Feeling the approach of even more serious shocks, people hurried to exchange paper money for at least some things. Owners of commission shops did their business on this tendency. One of these shops, a small one, where could be accommodated at the same time only 40-50 people, was overcrowded in mid-November. Crowd occurred not only inside but also outside. The owner asked the public not to squeeze out the window: "It costs over five thousands, more than all things at this auction! Don't stuck!". And he continued the auction: "Wonderful sea shell, 50 kopecks, who gives more? Wonderful children's shoes, a bit worn, 50 kopecks, who gives more?". The girl said to her mother: "My doll will be sold soon!" The village woman in a scarf bought cover for the light bulbs. The owner was surprised: "Why? You do not have an electricity." The countrywoman proudly replied: "Let me have it, not only rich men can have a lump covers!"18.

In the late autumn of 1918, on the final days of the hetman's rule, there were fewer and fewer opportunities for evening walks and rest in Kharkov: "There is no trams - you won't get far by walking. The streets are dark, and causing fear" "19. However, the residents of Kiev were almost less surprised by the forthcoming of the Petliurists in December 1918 than by the first approaching of the Bolsheviks in January of the same year. "The population got used to artillery shooting, without noticing the buzz of the guns, the public was walking, laughing, going to the cinema" 20 .

Anarchy was established between the Petlura's army and the Red's army in Kiev. This period lasted a whole week. During this time, the entire population was convinced that the absence of a government is also a kind of the ruling system, "and, moreover, perhaps not the worst form". The city was in perfect calm, shops were opened, there was a brisk trade

\footnotetext{
16 Из путевых заметок беженца кн. Е.Н. Трубецкого // АРР. Том 18. Берлин, издательство «Слово», 1926 г. - С. 143.

17 ЦДАГО, ф. 5, оп. 1, спр. 21, арк. 81зв.

18 Полтавские новости. 31 октября (13 ноября) 1918 г. № 156.

19 Южное слово (Харьков). № 2. 30 октября 1918 г.

20 Державний архів Російської Федерації (ДАРФ), ф. 5881, оп. 2, спр. 232, арк. 89.
} 
in the markets, and cab drivers were ready to serve those who wanted. "It was just somehow uncomfortably quiet" ${ }^{\text {"21 }}$.

Since February 1919, with the arrival of the Bolsheviks, the Kiev inhabitants have increasingly lost the isolation of their regular little world. Now a complete rest was not possible not only in public places, but also in their own homes. The military units of the Reds that entered the city settled in apartments. The family of the Kiev student was forced to give a space, and to accept two Red Army men. They asked for a tea. "I had to stand up and warm for them water, because the servants, who were obviously on their side, still refused to work at such an inappropriate time". The usual conditions of apartments disappeared, the whole city was filled with carts loaded with requisitioned furniture. "stylish furniture, carpets, mirrors" had been brought to the new Soviet. Private libraries were destroyed. The streets of Kiev has changed a lot. The number of elegant, and even neatly dressed people, especially men, has decreased ${ }^{22}$. Kiev's crowd has become "new" and "unusual". Officer V.V. Korsak noted that it was not "an old familiar population, where everyone could be recognized in his place: this is a teacher, this is a merchant, this is a foreigner, this is a cheat" 23 .

The trams stopped moving, there were almost no cab drivers, some shops were closed, others still somehow existed, waiting for the unavoidable end. But life was still felt in Kiev. The noisy southern crowd was still in a hurry somewhere, "it was only slightly worn out", "all sorts of coffee shops and pate restaurants were full. A full-blooded, sanguine city, feeding from the fruitful black-ground fields, did not give in to Bolshevik's poison. How all this does not look like Petersburg! The strict, gloomy capital city flared up with a crazy red flame, and died. Kiev wants to live, by all means, even with the Bolsheviks"24.

Very quickly, many families lost signs of external culture. As it showed out, even higher education was not a guarantee against extreme negligence and uncleanliness. Many Kiev intellectuals stopped cleaning their apartments, started to dry their laundry in the living rooms and on

\footnotetext{
${ }^{21}$ Революция на Украине по мемуарам белых. - С. 52.

22 Дневник и воспоминания киевской студентки. - С. 209-211.

23 Красная смута: сб. ист. лит. произв. М.: Содружество «Посев», 2011. - С. 145. C. 230.

${ }^{24}$ Раппопорт Ю.К. У красных и у белых // АРР. Том 20. Берлин, издательство «Слово», 1930 г. -
} 
the front balconies, were making the dough and cutting the cutlets on the wood buffets, never took out buckets of waste, walked all day in dirty bonnets ${ }^{25}$.

Private house has lost not only comfort, but also security. Every doorbell caused a feeling of horror, people began to be afraid to leave the house even for an hour, because something could happen during the absence. Some people for months did not leave the house. The soldiers, rushing into the apartments, searching everywhere, including the beds. The feeling of a "real, thorough search" was "as if stripped in public", especially when looking at letters and books. Throughout the stay of the Bolsheviks, the Kiev's citizens hid their property with their friends, "like a thief stoles goods" 26 .

The problem was the usual buying. Shops either completely disappeared or changed their profile. The Soviet flower trade was opened in the tea shop. In the first jewelry cooperative the selling of vegetables started. For some reason, street books trading has not been banned yet, and at every corner was a stand, or a kiosk, "over full of excellent publications". The books were "almost all with initials, many with inscriptions". The streets that changed their names became "more sadder and empty". Squares and parks were "uglified by the frightful busts of Soviet leaders". The number of "ugly futuristic posters" has increased. The benches in the gardens almost disappeared, many old trees in the parks were cut down. "Mariinsky Garden has turned into a graveyard"27.

The attack of the Volunteer Army for a short time freed bourgeois class from the fear of red terror. Before the arrival of volunteers, Kiev looked terrible. Everything looked dead, boarded up, only soldiers ran through the streets and shot into the air. The city was empty, "there were very few street walkers", however, local gangsters began to rob, "shouts and calls for help were heard everywhere" 28 .

After the final occupation of the city by army of whites, the streets were again filled with crowds of people. "Just yesterday, each one could think that Kiev was completely emptied, and today - there are dressed up women, military men in uniforms and with orders, officials - with

\footnotetext{
${ }^{25}$ Дневник и воспоминания киевской студентки. - С. 220.

26 Там же. - C. 217

27 Там же. - C. 224.

${ }^{28}$ Красная смута. - С. 188.
} 
buttonholes and badges". Next morning long lines formed near to the newspaper's stands, where the first "Kievlyanin" has been sold after a long break ${ }^{29}$.

The townspeople got used to the fightings. There was no single resident of Kiev who could not distinguish a shot from a explosion, and even "the kind of gun that is being shot" 30 . In the late autumn of 1919, city apartments finally lost the last signs of home comfort. People continued to go down both physically and morally. In some apartments the returned tenants put everything in order, in most others people lived indifferently "among the remains belonged to others". One of the student's acquaintances lived in a dirty, neglected apartment, there were broken dishes and a torn tablecloth on the table, and the owner herself wore several different dresses ${ }^{31}$.

In February 1920 Kiev seemed completely extinct, the trams did not move for a long time, only occasionally drivers drove by. On a dark and empty train station only a few people were seen with sacks on their backs. On some streets it was difficult to walk, sidewalks came to such a destroyed state ${ }^{32}$.

In Odessa, in the last days of the volunteers' stay, even the street of the outskirts was lit, although dimly. Despite the lighting and the trams full of passengers, Odessa citizens were robbed by bandits hiding in abandoned quarries. Robberies took place not only on the streets, but also in the apartments. No city in Russia, Prince Trubetskoy claimed, had such a number of robberies - "day and night, in the streets and in houses". Going out in the evening was dangerous. The Prince did not remember a single evening in Odessa "without many shots". One of his acquaintances, returning home late at night after meeting the New Year, counted more than one hundred and forty shots during the way ${ }^{33}$. Even if a friend's walk home lasted about one hour, anyway they shot two or three times in a minute.

Colonel of Wrangel's army compared the situation on the city streets under the Red and White armies: "I remember our White army.

\footnotetext{
${ }^{29}$ Красная смута. - С. 194.

30 Очерки жизни в Киеве в 1919-1920 гг. - С. 219.

31 Дневник и воспоминания киевской студентки. - С. 239.

32 Там же. - C. 236.

${ }^{33}$ Из путевых заметок беженца кн. Е.Н. Трубецкого. - С. 164.
} 
Occupation of a new city. Excited population, traffic and noise on the streets. Restaurants and places for entertainment are open, people are everywhere, delight, wine, drunk people could be met on the streets. In the city unauthorized searches, arrests, riot, gunshots are heard at night". After the Red army came, all was quiet. "Residents are sitting at home and, of course, afraid. There are few people on the street, restaurants are closed, there are no drunkards, no roistering and searches too, no shooting has been heard yet" $" 34$.

Against such a kind of life, a white Crimea looked like a fairy tale. During presence of Wrangel, the streets of Sevastopol were full of people. "Cab drivers, cars, announcements of concerts, lectures, meetings, money-changing shops at every step, shops, luxury shopwindows, and all of these, whatever. Cafes, restaurants ..." $" 35$. During the evacuation of the White army from the Crimea, the evening Simferopol had the usual appearance. "The brightly lit cafes were, as always, filled with military and civilian speculators, exhaling cheerful sounds of the orchestra in clouds of steam and tobacco smoke through the doors opened to the frosty street" 36 .

The situation in Kiev between the leaving of the Reds and the coming of the Poles contemporaries called "the strange days". The city was quiet and calm, the streets were completely empty, all establishments stopped working. The markets were empty too ${ }^{37}$. From the outside, the city experienced an "idyllic state". It was a beautiful weather, lush green blossomed. All stayed at home. "Only the brave souls decided to leave far to the center of the city. In the afternoon, bunches of curious people crowded at the doors, at the entrances" 38 .

Lawyer from Kiev, A.A. Goldenweiser, described his contemporaries in a gloomy colors: "They walked on the dead streets of the city, looking at the exhausted and stupid faces of passersby. They read newspapers stuck on the walls, telling about the revolution in Lisbon, and about the victory on some kind of newly invented front" ${ }^{\prime 39}$. The poverty and

${ }_{35}^{34}$ ДАРФ, ф. 5881, оп. 1, спр. 158, арк. 34.

35 Шульгин В.В. Дни. 1920: Записки. - М.: Современник, 1989. - С. 457.

36 Оболенский В. Крым при Врангеле. Мемуары белогвардейца. М.-Л.: Государственное издательство, 1927. - С. 74.

37 Заславский Д.О. Поляки в Киеве в 1920 году. - Петроград: изд-во «Былое», 1922. - С. 10.

${ }^{38}$ Там же. - С. 47.

${ }^{39}$ Гольденвейзер А.А. Из киевских воспоминаний // АРР. М.: Терра-Политиздат, 1991. т. 6. - С. 303. 
cheapness of the new life was expressed, first of all, in "how much important the ordinary things began to be" 40 .

Colonel of the Wrangel Army described the situation in the Crimea after the Whites left: "Revolutions are being made by ideas in alliance with the fear of hunger, but not with hunger". If a person got used to "pressed caviar, oysters, asparagus and grouse", then hunger begins for him when, by force of circumstances, "he will be placed in front of a plate of fat soup with cereal". For a person accustomed to pea soup with bacon and big piece of bread, hunger begins when "he will sit in front of a slice of bread and a cup of water". For the colonel, a real hunger began, when under the large linden tree growing near to his house in one of the gardens of the Crimea, "the last handful of seeds, fell from it, was collected" 41 .

The colonel paid an attention to the specifics of women's behavior under the Bolsheviks. All Soviet institutions "were filled with women and girls of two types - either pretty from the bourgeois environment, or ugly party members". Many ladies of noble birth went to serve in the Cheka, lived with red commanders, participated in feasts. "This phenomenon was more closely related to psychiatry than to virtue and women's honor". The real danger to life, ongoing shootings, a shortage of staff, made for these women a special "love elixir of death". True love and passion, laughter and smile, flowers and songs temporarily stopped to exist for many people ${ }^{42}$.

\section{Attempts of psychological adaptation}

The events occurring in the conditions of revolution and civil war, and the reaction to them of ordinary citizens, more and more were looking like a theater of the absurd. Just a week after the Bolshevik's revolution in Petrograd, residents of Ukrainian cities already knew the price of the new self-styled rulers of Russia. A modest, intelligent gentleman came to the kerosene trade place and asked to allow him to buy out of the line: "Please, give me kerosene, to cook a soup for my sick wife!". The line was relentless: "We have been standing here since sunrise, stand in the line!" The gentleman moved aside, put on inside out his coat, put on the

\footnotetext{
${ }^{40}$ Гольденвейзер А.А. Из киевских воспоминаний // АРР. М.: Терра-Политиздат, 1991. т. 6. - С. 301.

41 ДАРФ, ф. 5881, оп. 1, спр. 158, арк. 69.

42 ДАРФ, ф. 5881, оп. 1, спр. 158, арк. 74.
} 
cap, came back, and shouted: "Give me the way! The Bolshevik is coming!" The line ran instantly ${ }^{43}$.

A significant part of the comical situations in the first period of the revolution arose as a result of the actions of the new government, and was reflected in the reaction of citizens to its decisions and resolutions. In December 1917, the Bolshevik Decree "The rules of divorce" was issued, establishing the right to break up the marital relations. Already in January 1918 , the readers of the "Free South" learned about the brave action of one of the residents of Sevastopol. Since the decree on divorces did not reach Sevastopol, and he asked for divorce, he announced to all readers of the newspaper that he considered himself a divorced by "present statement". The reason for the divorce was the "shameful behavior" of his wife. Moreover, the fact of shameful behavior was confirmed by "citizens X. and U." ${ }^{, 44}$.

Another category of everyday events that provided a lot causes for jokes, were numerous domestic and family difficulties caused by the economic crisis. The revolutionary epoch caused many new problems for city residents which were primarily related to the satisfaction of basic needs in the context of numerous social experiments. In the implementation of their needs, the inhabitants showed miracles of adaptability. They were exhausted from the endless "tails" for a variety of goods, but still could be ironic on this topic. "It's good if the tail is manufactory - you stood for two days, got a ticket - can go home and enjoy! But that one who smokes, in the tobacco tail, has a trouble ..." "Why?" - "While waiting in boredom and cold, he smokes twice more... As long as he waits - he will smoke all old stock, therefore, it is necessary to make a stock again! So he will stay all his life in the tobacco tail!"45.

Odessans did not lose their sense of humor. One of them, the head of the family, sent all his household "to different strategic points of the city" in order to get bread. When all the family members gathered around the dinner table, they had apples, watermelons, plums, and "all other food" in their hands. Only bread was not there. The man went to the neighbor, asked him for a piece of bread "instead of his wedding black jacket", and

\footnotetext{
${ }^{43}$ Одесская почта. № 3187, 19 ноября 1917 г.

${ }_{45}^{4}$ Вольный Юг (Севастополь). № 41. 17 января 1918 г.

${ }^{45}$ Киевская мысль. № 104. 26 сентября 1917 г.
} 
his family "began to eat this bread like a gingerbread". After lunch, his wife categorically stated that she regretted about her marriage. "Nowadays is better to marry a shoemaker. And the best - to a baker. Such a man's wife will never need bread"46.

The realities of the new time were reflected in the eternal, like the world, relations between men and women. In one of the families a woo took place. The bride was a respectable person in her forties. The groom was stubborn. A matchmaker asked: "Do you like a bride?". The groom was adamant: "She looks like a monkey!" - "She has a wardrobe!" - "To hell!" - "Dowry is five thousands", the matchmaker added. - "What is the current rate of five thousands? I do not want to!" - And then the father of the bride intervened: "I will give ten pounds of sugar and two coupons for galoshes for my daughter". - "I agree!"- the groom happily said. The wedding took place in two weeks ${ }^{47}$.

The period of Hetman P.P. Skoropadsky brought certain positive changes in food supply and in other areas of life, but the episodes that have been caused the jokes did not become less. A large amount of comical information was presented by the histories of refugees from Soviet Russia, the flow of which rushed into the hetman's Ukraine in the spring and summer of 1918. The hetman who was distinguished for his brilliant observation, described the different stages of refugee behavior in his memoirs. At first, after the arrival, "the person is silent, sleeps, drinks and eats". At the second stage, the euphoria comes - "Ukraine is lovely, the language is so euphonic, the climate is good, Kiev is beautiful, the government is good". The third stage already contains elements of criticism - "cab drivers are very bad, the pavement in some places is broken". At the last stage, an active negation prevailed: "Your Ukraine is nonsense, it has no data for existence, and there are no Ukrainians, all this is an invention of the Germans" $" 48$.

To get out of Soviet Russia, people showed maximum ingenuity. The Bolsheviks more easier were giving permissions to travel to all kinds of artists, therefore, various opera and drama troupes moved to the south by hundreds. A famous barber from Petrograd told to a Russian journalist,

\footnotetext{
${ }^{46}$ Одесская почта. № 3134, 19 сентября 1917 г.

${ }^{47}$ Одесская почта. № 3187, 19 ноября 1917 г.

48 Скоропадський П. Вказ. тв. - С. 226, 227.
} 
Teffy, that he and several members of his family were responsible for different roles. In the troupe there were "first lover", "ingenue", "grandcoquette", mother-in-law in a role of cashier, and eleven (!) prompters. "Of course, the proletariat was a little bit confused by this number of prompters. But we explained that this is the most crucial element of art. Without a prompter the play cannot go. On the other hand, the prompter, sitting in a booth and being restricted in his movements, quickly becomes exhausted and must be immediately replaced with a fresh one"49.

During the few months of life under the Bolsheviks' ruling the world perception of citizens was distorted, and in the summer of 1918, when they found themselves in a prosperous Ukraine, they would hardly forget the Soviet realities. Teffi's daughter bought a chocolate in one of the Ukrainian towns. The family was surprised that "no one asked any papers, and no one stand in line", but simply entered the shop and bought it. It was decided to try is it really a chocolate, and then buy more. But her daughter said that next time someone else should go for the chocolate, "otherwise it will seem suspicious" 50 .

The Germans were faced with the specificities of local life, when was useless to fight, and remained to call on conscience and mercy. In April 1918, a pickpocket successfully worked during a performance at the Empire Theater. As a result, the South Region newspaper asked the thief who stole a wallet with money and documents, "to return at least the documents to the poor German soldier in his regiment, at the address indicated on the documents" ${ }^{, 51}$.

The housing crisis was rising. The cessation of new building works and the flow of refugees had a negative effect on the state of the housing stock. Kharkiv students had to rent extremely small apartments with minimal amenities. On this occasion, journalists could still joke. Here is the hostess's dialogue with the student: "What am I going to do to my table?" - "The medic student stayed before you. He used to sit on the bed, putting his book on his lap. Every person could be his own table". "There is no place even to put a chair here". - "Why do you need a chair?" - "In case if my friend comes to me?" - "Why should he come to

\footnotetext{
49 Тэффи Н.А. Житье-бытье: Рассказы. Воспоминания. - М.: Политиздат, 1991. - С. 339.

${ }^{50}$ Тэффи Н.А. Указ. соч. - С. 292-293.

${ }^{51}$ Южный край. 30 апреля 1918 г.
} 
you? Would be better visit him yourself". - "You mentioned - apartment has a light". - "There is lantern's light from the street outside your window. And whole night there is free lighting. We are gathering a "reading hall" here on the windowsill",52.

The presence of Austro-German army units in the country did not provide complete security, the threat of bandit attacks remained. On the steamers that navigated in 1918 from Kiev to Yekaterinoslav and back, enterprising people appeared at various stops, offering to passengers clean 96-degree alcohol for twenty rubles per bottle. "Passengers sniffed, made a deal, swore", and eventually bought alcohol "for a holidays". On the next stop, the alcohol owners while moving down from the ship "were surrounded by a group in gray coats", and unceremoniously searched, "not sparing even baskets and suitcases". At the same time, alcohol was confiscated, but after that a new trade began on the ship. At the next station, the same thing happened, and this way it went on to the final destination. The assistant captain said that the same bottles of alcohol "walks back and forth from the starting of navigation", and, obviously, "will walk during the whole season"

People did not lose courage, and, at the first chance for someone to cheat and have their own benefit, they actively used this opportunity. At the end of October 1918, in the last weeks of the hetman's reign, the newspaper "Yuzhnoye Slovo" published Mikhail Koltsov's feuilleton about the behavior of Kharkov residents when distributing coupons for purchasing the vodka. Under the pen of a talented journalist, the constant desire of the philistines to outwit others, including administrators, has achieved the degree of grotesque. "Young lady! Give it to me! - And to me! - Do not meddle out of turn! What a mess! - I can not give it to you. Your passport does not have a registration. - Have mercy! We have already prepared the snack! Tomatoes will spoil. Feel our bad situation!" One of the Kharkov citizens tried to get a ticket for a six-year-old daughter: "I have a girl exactly like an old one! Drinking alcohol for my respect. It is impossible without this!" The member of the housing committee wanted to receive the coupon for two buckets at once: "We supposed that we would get two buckets and distribute them among our

\footnotetext{
${ }^{52}$ Южный край. 14 августа 1918 г.

${ }^{53}$ Южная заря (Екатеринослав). № 2. 10 мая 1918 г.
} 
house residents". Another lover of liquor, single by a passport, demanded two coupons: "Although we didn't have a priest, I have lived eight years with Anisya, she is my completely legal wife". And it was only about coupons, the confirmed distribution of alcohol could not take place. However, downstairs, at the entrance, a group of excited citizens crowded, having already received precious coupons ${ }^{54}$.

Junker Yakonovsky had his way to the Don with many adventures: "Our train, principally, goes to Kharkov through Lyubotin, but, of course, only principally. To make this happen, it is necessary that in Kharkov there should be the same power as in Sumy and Lyubotin. Last night there were Petliurists everywhere. Today, there are still Petliurists in Lyubotin, but already Bolsheviks in Kharkov. We do not immediately recognize this". In Kremenchug, the cadets with help of the tea house owner negotiated with the railway workers to continue the trip, and received the following answer: "We'll let the train go, just buy the firewood, pay the brigade and the station authorities. We will go to Nikolaev, and where we will reach, this is something we don't know"55.

The approach of the Red soldiers to Kiev was accompanied by the spread of a fantastic tale, with the help of which the urban community explained the slowdown in their progress. There was a rumor that the Petliurists drove off the Bolsheviks behind Nezhyn with the help of some kind of magic lantern. From the proclamation issued by the Directory, it became known that the Ukrainian army received from the French some "purple rays" lantern, from which people supposedly lost sight for six months, and then lit up the Bolshevik force detachment with "some kind of a purple searchlight". They said that "this farce delayed the situation for several days"

The Bolsheviks "exhausted the soul of the population" with their orders. The first order suggested the evacuation of the bourgeoisie from their apartments, and the settlement of the poor people there. "There was no bourgeois at all". All residents of Kiev turned out to be "honest workers in the course of formation and strengthening of the Soviet

\footnotetext{
${ }_{55}^{54}$ Южное слово (Харьков). № 2. 30 октября 1918 г.

55 Яконовский Е. Фарфоровая кокарда. [Электронный ресурс] - Режим доступа: http://www.dk1868.ru/history/FARF_KOK.htm.

${ }^{56}$ Раппопорт Ю.К. Указ. соч. - С. 209.
} 
power", all were supplied with the appropriate papers, "you will not reproach anyone!"57.

During searches in family apartments, they were got all together, and all residents were having cherished "papers" - certificates of belonging to one or another category of the privileged class - to Soviet employees, artists, members of trade unions, etc. ${ }^{58}$.

V.V. Korsak, who was in Kiev with the Reds, got a job at the council of the national economy. The head of the general department said that he had many departments and posts. "But no food allowances", the meager salary, so that all newly received "began to lose weight". The life of the Soviet institution was characterized as "paper-ink work". Schools, hospitals, bridges, theaters, folk houses were built only on paper, in reality there were no nails and axes. A fast survey of visitors ended with the fact that "some were sent to the floor above, others - to the floor below, third - to the council, fourth - to the executive committee; briefly, all was not blessed by God" ${ }^{\text {"59. }}$.

When the Volunteer Army appeared in the Donbass, employees of various institutions, in order to maintain their positions, once again urgently changed their political beliefs. The head of the Shterovka railway station became "over right", although at different times, under different authorities, he managed to stay both "German" and "Ukrainian" and "Red" 60 .

The onset of the Volunteer Army allowed the townsfolk to return to their hometowns. But not all perceived Denikin's success with full enthusiasm. Teffi's friend from Kharkov, whom she met walking on the street by the hand with a young actress, made a helpless gesture and confusedly said: "Why are they moving so soon! Though would rest a little. Do you not find that it is better to give the soldiers to take a breath? Of course, they are heroes, but the respite is not harmful even to the hero". And hopelessly he added: "After all, it's probably time to go home soon". He had a wife in Kharkov, about which Teffi knew that she was not thrilled by the quick White's attack too. "I suppose, after each new report of the White's successes, she wanders around the house, tears up letters,

\footnotetext{
57 Очерки жизни в Киеве в 1919-1920 гг. - С. 211-212.

${ }^{58}$ Гольденвейзер А.А. Указ. соч. - С. 239.

${ }^{59}$ Красная смута. - С. 168.

60 ДАРФ, ф. Р-440, оп. 1, спр. 34, арк. 14.
} 
shakes suspicious cigarette butts out of ashtrays and writes a little note with a trembling hand: "Whites are approaching. Just in case, do not come tomorrow" $"$.

During the next attack on Kiev, the Kiev citizen L. and all her relatives gathered in the same apartment and searched for the safest room. This happened as follows. At first there was a discussion from which of the four cardinal sides the attack was coming. Then, "almost with a compass in hand", this side was sought. The knowledge of where the bomb should not logically fall, did not help much - nothing prevented that the bomb could "sometimes be thrown there". Residents tried to determine exactly who is leading, calculated the amount of water available, and for how long it might be enough. One of the neighbors proposed the method of quenching his thirst invented by him - "sucking carrots". The hosts refused, saying that they would go to Dnepr for a water. "You will not go anywhere, but you will come to me for the carrot", the neighbor answered philosophically. When the authorities changed, the city plunged into anarchy, to which the inhabitants quickly became accustomed. In such cases, some unknown people with bands on their arms appeared on the streets. "Whether they are robbing, or protecting from robbers, nobody knows exactly. They say that there are real ones that protect, and fake ones that rob" ${ }^{\text {. }}$.

In Odessa on the eve of the arrival of the Bolsheviks, the bandits also became more active. But the townspeople could not sit at home, and in the evenings "got out of their unheated apartments". People were visiting clubs and theaters, gathering to go home in groups, hiding valuable things on themselves, and hiring guards - "five students, armed with whatever they got". But it all did a little help. The woman who suffered from the bandit raid complained: "He, a sneaky man, listens to where it is ticking, and searches there. I said - this is my heartbeat because of fear. Do they believe a honest person!"63.

Another series of tragicomic situations is associated with the third coming of the Bolsheviks to Ukraine. The head of the Kharkov provincial department of public education forbade the management department to do

\footnotetext{
${ }^{61}$ Тэффи Н.А. Указ. соч. - С. 398-399.

62 Очерки жизни в Киеве в 1919-1920 гг. - С. 226.

${ }^{63}$ Тэффи Н.А. Указ. соч. - С. 331.
} 
"performance and dance evening" in the building of a college of crafting. Firstly, because evening classes of the college and courses for workers took place there, and secondly, because latrines were idle there, and there was no heating. It turned out that students of the college and cadet workers had neither latrines nor heating required ${ }^{64}$.

In the summer of 1920, the niggling Bolshevik's regulation related to the property of citizens reached its apogee. A.A. Goldenweiser was ironic about this: "To move the mattress from one apartment to another, I needed an order; to move to the next station, a pass was needed; in order to buy a sheet of paper, it was necessary to pre-write several sheets with requests for the proper permission" 65 .

People's ability to adapt to changes of the living conditions was unique. When the Bolsheviks banned private marketing, they still accepted the existence of cooperatives. "And, like a magic, all the private tradings declared themselves cooperatives". Then the cooperatives were closed, but handicraft workshops remained allowed. "In a short time, all the shopkeepers on Vasilkovskaya and Podol turned out to be craftsmen, and they started making gasoline lighters and rubber soles from stolen car tires". Finally, trade was limited only to food products, and right there "in all the shops, bread and boxes of tea substitutes appeared in the windows; the rest of the goods were been selling in the back rooms". When any trade was banned, shopkeepers used living places to sell staffs. Goldenweiser remembered a shopkeeper living in the same house: "The front room of the shop was turned into a living room, and through the windows everyone could see from the street, in the place where depravity of speculation reigned before, now the family of peaceful proletarians Hirschman eats and drinks tea. Trade at that time was carried out in the shopkeeper's previously living room, which was on the side of the courtyard",66.

One of the sides of activities of the Soviet government was the increasing role of the bureaucratic apparatus. According to the writer V.P. Kataev, "every person with a briefcase seemed to be a creature of the highest order, all-knowing and all-powerful". The abbreviated names of

\footnotetext{
${ }_{64}^{64}$ Державний архів Харківської області (ДАХО), ф. Р-202, оп. 1, спр. 11с, арк. 222.

65 Гольденвейзер А.А. Указ. соч. - С. 286.

66 Там же.
} 
institutions, adopted by the Bolsheviks, "put terrified intellectuals in a horror" ${ }^{\prime 67}$.

Once being in Odessa, occupied by Red soldiers, monarchist V.V. Shulgin got to the police station, where he has been checked for his documents. The check took place under the light of some kind of oil lamp, which was considered a lamp. The information of the detained citizen was decided to be immediately clarified in the address table, the call to which was accompanied by the words: "What? No light in the address table? You cannot give any help? What? Did you harm your head? By what? Oh wardrobe? What a disgrace ...". The story ended well - Shulgin was not only released, but allowed to spend the night in the police station ${ }^{68}$.

Under the Bolsheviks, school teachers did not receive any payment for more than a year. They quickly found a way out, and "began to press on the students, to demonstrate an exceptional severity and exactingness towards them, with the result that the majority of students began to take a private lessons from them at home"

The difficulties of the economic situation were not caused only by poverty and lack of money. Even for those who had money, the question arose whether they had money able to buy something. During the Polish occupation of Kiev, the monetary issue became fantastically confusing and actual. An infinite number of money currencies was circulating: Soviet, Duma, Ukrainian, Royal, Kerensky's currency, Polish marks. For each of the 14 varieties of money was a special, and variable rate. And the prices of each product were different for each kind of currency ${ }^{70}$.

The soldiers of White army, who did not leave with Wrangel and remained in the Crimea, tried to "adopt to a proletarian features", so they started to work in re-sewing clothes. The colonel of the Russian army was working in hand-sewing, because the owners did not have a sewing machine. Dressing did not help everyone, for example, "my grandmother still kept an aristocratic look" appointed to follow a train carrying the Crimean wines to Moscow. There were twenty wagons in the train, and each wagon had twelve large barrels

\footnotetext{
${ }^{67}$ Катаев В. П. Почти дневник. - М.: Советский писатель, 1962. - С. 78.

68 Шульгин В.В. Дни. 1920: Записки. - С. 397.

${ }^{69}$ Мартынов А. Мои украинские впечатления и размышления. Москва-Петроград, Государственное издательство, 1923. - С. 52.

${ }_{70}$ Революция на Украине по мемуарам белых. - С. 62.

71 ДАРФ, ф. 5881, оп. 1, спр. 158, арк. 15.
} 
inside. The wine was old, aged. At each station, the local administration delayed the train under any causes, "transparently hinting about the need for a bribe for further movement". The people accompanying the train tried several times to ask for help of the Railway Emergency Commission (Cheka), but this only led to an "increase in the tax rate" 72 .

\section{FINDINGS}

The daily life of the population of large cities got a special character in crisis conditions. Cities as a product of civilization died with it. For urban dwellers, implementation of both sides of everyday life, both technological and mental, was extremely difficult. A lot of effort and wonders of ingenuity had to be applied to find ways to meet everyday needs - what to wear and where to live, how to move, what to use in work, education and leisure, how to take care of health. On the other hand, it was difficult for the townspeople to find a new semantic content for their life, to work out a system of life guidelines - how and why to live, what values to have, what moral principles to follow. The past habits, priorities, tastes were gone. On the peasants social changes were reflected less. The traditionalism of rural labor and life, relative detachment from power, closeness to the land as a source of rescue made the village an island of economic stability and political inertia.

The jokes about main themes such as actions and orders of the government in the period of 1917-1920, and numerous domestic troubles, were sometimes reaching to the point of absurdity. It is notable that the surrounding reality was able to cause people's laughter only in the initial period of the revolution. Be ironic about later events people could only after some time. Crazy rumors gave food for humor, circulating from time to time in society, and citizens' attempted to live like nothing had happened, distancing themselves from the ruling power. Of course, the observer's vision from the side usually was causing him to have completely different emotions than the person who was directly in the center of events. The main thing is that people did not lose the ability to laugh, even through tears, and the need for laughter, as a means of psychological protection, remained in the most difficult times.

\footnotetext{
${ }^{72}$ ДАРФ, ф. 5881, оп. 1, спр. 158, арк. 169.
} 


\section{SUMMARY}

During the Revolution and Civil War of 1917-1920, the population of Ukrainian cities experienced significant upheavals caused by the change of powers and hostilities. These shocks gradually transformed social and individual psychology. Gradually losing interest in politics, urban residents preferred to spend their time searching for products. Every day they felt less secure. The closeness of the familiar little world of everyday life was destroyed. Familiar atmosphere of the apartments disappeared, city streets changed. Many families lost signs of external culture very quickly.

The events that took place more and more resembled the theater of the absurd, while the citizens showed miracles of adaptability in realization of their needs. They quickly got used to the fact that during changing of the authorities the cities plunged into anarchy, learned to circumvent the ridiculous prohibitions of petty Bolshevik regulations and actively used the first opportunity to circle someone around their finger. Employees of various institutions repeatedly changed their political beliefs to maintain their positions. Thus, previous ethical standards ceased to exist for the commoners.

\section{REFERENCES}

1. Гольденвейзер А. А. Из киевских воспоминаний / А. А. Гольденвейзер // Архив русской революции / [изданный Г. В. Гессеном]. М. : Терра-Политиздат, 1991. - Т. 6. - 364 с.

2. Гуммерус Г. Україна в переломні часи. Шість місяців на чолі посольства у Києві / Герман Гуммерус ; [пер. 3 фін.]. - [2-е вид., випр. і допов.]. - К. : ВПЦ «Київ. ун-т», 2004. - 188 с.

3. Дневник и воспоминания киевской студентки (1919-1920 гг.) // Архив русской революции / [изд. Г. В. Гессеном]. - Берлин : Изд-во «Слово», 1924. - Т. 15. - 345 с.

4. Заславский Д.О. Поляки в Киеве в 1920 году / Д. О. Заславский. - Петроград : Изд-во «Былое», 1922. - 48 с.

5. Катаев В. П. Почти дневник / В. П. Катаев. - М. : Советский писатель, 1962. -544 с. 
6. Корсак В. В. (Завадский). У красных. У белых. Великий исход / В. В. Корсак // Красная смута: сб. ист. лит. произв. / [сост. Р. Г. Гагкуев]. - М. : Содружество «Посев», 2011. - 624 с.

7. Кришевский Н. В Крыму (1916-1918 г.) / Н. Кришевский // Архив русской революции / [издаваемый Г. В. Гессеном]. - Берлин : Изд-во «Слово», 1924. - Том 13. - 312 с.

8. Левкович М. Женщина в революции и гражданской войне на Украине / М. Левкович. - Харьков : Книгоспилка, 1928. - 92 с.

9. Лейхтенбергский Г. Н. Воспоминания об «Украине». 19171918 / Г. Н. Лейхтенбергский ; [авторизованный пер. с франц.]. Берлин : Детинец, 1921. - 52 с.

10. Мартынов А. Мои украинские впечатления и размышления / А. Мартынов. - Москва-Петроград : Гос. изд-во, 1923. - 75 с.

11. Оболенский В. Крым при Врангеле. Мемуары белогвардейца / В. Оболенский. - М.-Л. : Гос. изд-во, 1927. - 86 с.

12. Омелянович-Павленко М. В. Спогади командарма (19171920): Документально-художнє видання / М. В. ОмеляновичПавленко ; [упоряд.: М. Ковальчук]. - К. : Темпора, 2007. - 608 с.

13. Очерки жизни в Киеве в 1919-1920 гг. // Архив русской революции / [изданный Г. В. Гессеном]. - М. : Терра-Политиздат, 1991. - T. 3. - 274 c.

14. Раппопорт Ю. К. У красных и у белых / Ю. К. Раппопорт // Архив русской революции / [издаваемый Г. В. Гессеном]. - Берлин : Изд-во «Слово», 1930. - Том 20. - 322 с.

15. Революция на Украине по мемуарам белых / Сост. С. А. Алексеев, под редакцией Н.Н. Попова. - Москва-Ленинград: Государственное издательство., 1930 г. Репринтное воспроизведение издания 1930 г. Киев: Политиздат, 1990 г. - 436 с.

16. Скоропадський П. П. Спогади. Кінець 1917 - грудень 1918 рр. / П. П. Скоропадський ; [гол. ред. Я. Пеленський]. - КиївФіладельфія, 1995. - 494 с.

17. Трубецкой Е. Н. Из путевых заметок беженца / Е. Н. Трубецкой // Архив русской революции / [изданный Г. В. Гессеном]. Берлин : Изд-во «Слово», 1926. - Т. 18. - 319 с.

18. Тэффи Н. А. Житье-бытье: Рассказы. Воспоминания / Н. А. Тэффи. - М. : Политиздат, 1991. - 445 с. 
19. Шульгин В. В. Дни. 1920: Записки / В. В. Шульгин ; [сост. и авт. вст. ст. Д. А. Жуков]. - М. : Современник, 1989. - 559 с.

20. Яконовский Е. Фарфоровая кокарда. [Электронный ресурс] Режим доступа: http://www.dk1868.ru/history/FARF_KOK.htm.

\section{Information about the author:} Popov V. Z.

dr. history sciences, professor V.I. Vernadsky Taurida National University 01133, Ukraine, Kyiv, 33 Ivana Kudry Str. 